\title{
Physical and Antimicrobial Properties of Hydroxypropyl Starch Bio-plastics Incorporated with Nyamplung (Calophyllum inophyllum) Cake Extract as an Eco-Friendly Food Packaging
}

\author{
Rini Umiyati ${ }^{1,3, *}$, Chusnul Hidayat ${ }^{1}$, Ria Millati $^{1}$, and Teguh Ariyanto ${ }^{2}$ \\ ${ }^{1}$ Department of Food and Agricultural Product Technology, Faculty of Agriculture Technology, University of Gadjah Mada, Jl. Flora \\ Yogyakarta 55281, Indonesia \\ ${ }^{2}$ Department of Chemical Engineering, Faculty of Engineering, University of Gadjah Mada, Jl. Teknika Utara Yogyakarta 55281, \\ Indonesia \\ ${ }^{3}$ Department of Food Technology, Faculty of Engineering, University of PGRI Semarang, Jl. Sidodadi Timur no. 24, Semarang, \\ Indonesia
}

\begin{abstract}
Nyamplung (Calophyllum inophyllum) cake as a by-product of nyamplung oil production is still limited. This research aimed to evaluate characteristics of antimicrobial bio-plastic made from hydroxypropyl starch as a basic ingredient and Nyamplung cake extract as additive. Nyamplung cake extract addition affected bio-plastic mechanical property by reduction of tensile strength but improved physical properties by reduction of vapor and oxygen permeability, water solubility, and increased elongation. This was probably due to the extract serve as natural crosslinking. Fourier Transform Infrared Spectroscopy analysis showed no difference in five bio-plastic samples, which probably caused by low concentration of extract. Thermogravimetry analysis showed the highest weight reduction in control of $95.824 \%$ and the lowest on Ext2\% of $84.471 \%$. Morphology analysis showed agglomeration of the extract on sample surface due to uneven ingredient distribution in mixture. Bio-plastic was more sensitive against gram positive bacteria than gram negative with their respective largest inhibition zone of $30 \mathrm{~mm}$ (Staphylococcus aureus) and $23 \mathrm{~mm}$ (Escherichia coli). This was probably due to the content of the extract serve as natural crosslinking and antibacterial agent.
\end{abstract}

Keywords: bio-plastic; inhibition zone; solubility; tensile strength; vapor permeability; oxygen permeability.

\section{Introduction}

The main function of packaging is to isolate food from the environment to minimize food defects during distribution by reducing air pressure, humidity, gas, odor, and mechanical strength. Packaging avoids the exposure of food to degradation agents and also prevents food from microorganism contamination [1,2]. In the last few decades, a large number of antimicrobial food packaging products have been developed, which able to control microbial growth and effectively extend food shelf life up to 2 weeks or more.

Antimicrobial agents in packaging materials are used to provide security assurance, to extend shelf life and food quality. Antimicrobial packaging can inhibit food decay and suppress pathogenic microbes in foods $[2,3]$. Biodegradable materials derived from renewable materials, such as those from polysaccharides, proteins, and lipids, have much more attention due to their potential to replace conventional plastics $[4,5]$.

Nowadays, there is an increase in consumers demand on environmentally friendly food packaging from natural sources without preservatives, while food processing industries also want to increase shelf life and product safety. Starch is one of the common ingredients used to produce environmentally friendly packaging. It consisting of the straight molecule (amylose) that form a gel when heated and branched molecules (amylopectin) [6].

In this study, hydroxypropyl starch (HPS) was used as the main material to overcome the weakness of native starch because the hydroxyl group, which is sensitive to air, is the main obstacle for the application of starchbased food packaging materials [7]. HPS $\left(\mathrm{C}_{13} \mathrm{H}_{56} \mathrm{O}_{22}\right)$ is a derivative starch or modified starch. Hydroxypropylation can be done through modification using propylene oxide $\left(\mathrm{C}_{3} \mathrm{H}_{6} \mathrm{O}\right)$. HPS is chemically modified through the conversion of hydroxyl group of glucose monomer into -O- (2-hydroxypropyl) group. HPS has a higher solubility compared to native starch [8].

High production cost is one of the causes for the low number of antimicrobial packaging materials in the market. Nyamplung cake as an ingredient for antimicrobial packaging material is expected to be a

\footnotetext{
* Corresponding author: riniruy@gmail.com
} 
solution to this problem because it is obtained as a byproduct after removal of oil from seeds [9]. Nowadays, the utilization of nyamplung cake is still limited. It is used as organic fertilizer or animal feed. This study aimed to evaluate the potential and its feasibility overview of nyamplung cake extract as an additional ingredient to produce antimicrobial packaging, in which HPS was as the main ingredient.

\section{Experimental Section}

\subsection{Materials}

Nyamplung cake was obtained from biodiesel industry in Purworejo, Central Java, Indonesia. Escherichia coli (gram-negative bacteria), Staphylococcus aureus (grampositive bacteria) and Aspergillus niger (fungi) were obtained from Biotechnology Center of University of Gsdjah Mada, Yogyakarta. HPS was obtained from Haihang Industry Co., LTD, Jinan City, Shandong, Province, China., glycerol and ethanol were obtained from Eco-green Oleochemicals, Indonesia and distilled water.

\subsection{Instruments}

The tools used in this research were hot press machine, FTIR (Thermo Scientific Nicolet iS10), SEM (JEOL JSM 6510), TGA (DTG-60), texture analyzer (Brookfield USA), analytical scale (Sartorius), sieves, mixers, stopwatches and a set of glassware.

\subsection{Procedure}

\subsubsection{Nyamplung Seed Cake Extraction}

Nyamplung seed cake extract was prepared by adding 20 $\mathrm{g}$ of 120 mesh nyamplung seed cake flour to $120 \mathrm{ml} 96 \%$ ethanol. Mixture was incubated at $80{ }^{\circ} \mathrm{C}$ for $1 \mathrm{~h}$. The mixture was then filtered using Whatman paper no. 1. Filtrate was then dried in oven dryer at $50{ }^{\circ} \mathrm{C}$ for $24 \mathrm{~h}$ [10].

\subsubsection{Bioplastic Preparation}

Bio-plastics were made by mixing $10 \mathrm{~g}$ HPS and various concentrations of Nyamplung cake $(0 \%, 0.5 \%, 1.5 \%$ and $2 \% \mathrm{w} / \mathrm{w}$ (dry base)), $2.5 \mathrm{~g}$ glycerol $(25 \% \mathrm{w} / \mathrm{w})$ as plasticizer and $1 \mathrm{~g}$ distilled water $(10 \% \mathrm{w} / \mathrm{w})$. Then the mixture was homogenized and pressed in thermocompression at $140{ }^{\circ} \mathrm{C}$ and pressure of $150 \mathrm{~kg} / \mathrm{cm}^{2}$ for 6 $\min [11]$.

\subsubsection{Mechanical Properties Analysis}

Mechanical properties test, such as tensile strength (TS), elongation at break (EI), and modulus of elasticity (MOE), was carried out using Brookfield USA analyzer texture. The five bio-plastics were cut into $30 \times 5 \mathrm{~mm}$.
Bio-plastics were held parallel with an initial grip separation of $15 \mathrm{~mm}$, and pull apart at a head speed of 25 $\mathrm{mm} / \mathrm{min}$. Tensile strength was calculated by dividing the maximum force.

\subsubsection{Water Vapor and Oxygen Permeability}

Water vapor permeability (WVP) of bioplastic was determined using a modified ASTME 96 procedure. Permeation cell (glass acrylic), which contained water and bioplastic, was closed tightly $(0 \% \mathrm{RH}$ and $0 \mathrm{~Pa}$ partial vapor pressure). The closed cell was placed in a control room at $70 \% \mathrm{RH}$ and maintained at $25{ }^{\circ} \mathrm{C}(2300$ $\mathrm{Pa}$, partial vapor pressure). After 20-24 h, when water vapor transmission reaches stationary, cell weight changes were recorded over a 4-day period to calculate WVP [12].

$$
W V P=\frac{E}{A . \Delta p} \frac{\Delta m}{\Delta t}
$$

where :

WVP : water vapor permeability, g/(m.s.Pa)

$\Delta \mathrm{m} / \Delta \mathrm{t} \quad$ : sample weight loss in time function, $\mathrm{g} / \mathrm{s}$

E : film thickness, $m$

A : permeability area, $8.55 \times 10^{-4} \mathrm{~m}^{2}$

$\Delta p \quad$ : pressure difference under the film and outside, $\mathrm{Pa}$

Analysis of oxygen transfer and other gases through packaging materials can be done as follows [13].

$$
Q=\frac{P A t}{L} \Delta p
$$

where :

Q : the total amount of permeation ( $\% . \mathrm{S} / \mathrm{mm} 2)$

$\mathrm{P} \quad$ : the permeability $(\% / \mathrm{s})$

A : the area of permeation $((\mathrm{mm} 2)$

$\mathrm{L} \quad$ : the thickness (mm)

$\Delta p \quad:$ the difference of the permeation across the diffusion path $(\%)$

\subsubsection{Water Solubility}

Water solubility analysis was carried out by soaking dry bio-plastics in $50 \mathrm{ml}$ distilled water, then put in the flash on shaking incubator at $25{ }^{\circ} \mathrm{C}$ for $24 \mathrm{~h}$. Bio-plastics were then taken and dried again (at $105{ }^{\circ} \mathrm{C}$ for $24 \mathrm{~h}$ ) to determine the weight of the dry material, which dissolved in the water. The mass of water-soluble was calculated by subtracting the initial dry mass with the mass of the insoluble dry matter and expressed as a percentage of the initial dry matter content [14].

\subsubsection{Antimicrobial Analysis}

Antimicrobial analysis of bio-plastics was carried out using agar diffusion method according to the optimized method described by Pranoto [15]. About $0.1 \mathrm{ml}$ suspension of $10 \%$ sample was spread into sodium agar medium and on malt extract agar media for bacteria and fungal strain, respectively. Well pits with $\pm 6 \mathrm{~mm}$ diameter in the media were used to put $\pm 6 \mathrm{~mm}$ the test 
samples and incubated at $40{ }^{\circ} \mathrm{C}$ for $1-2$ days, while fungi strain was incubated at $30{ }^{\circ} \mathrm{C}$ for $2-3$ days.

\subsubsection{Fourier Transform Infrared Spectroscopy (FTIR)}

FTIR spectroscopy was used to verify chemical structure changes of starch molecules [16]. The analysis was conducted using Thermo Scientific Nicolet iS10 FTIR, with Fast recovery Deuterated TriGlycine Sulphate (DTGS) detector type (standard); Liquid-nitrogen-cooled mercury cadmium telluride (MCT) (optional).

\subsubsection{Thermogravimetric Analysis (TGA)}

TGA analysis of bioplastic was carried out using TGA Analyzer-60. Approximately 5-10 mg samples were heated from room temperature up to $600{ }^{\circ} \mathrm{C}$ at heating rate of $10{ }^{\circ} \mathrm{C} / \mathrm{s}$, measured under high purity nitrogen atmosphere at $100 \mathrm{ml} / \mathrm{s}$ flow rate [17].

\subsubsection{Scanning Electron Microscopy}

Bio-plastics microstructure analysis was carried out by SEM. The sample was stored in a desiccator containing $\mathrm{P}_{2} \mathrm{O}_{5}$ for two weeks to ensure no water in the sample. To observe the cross-section, bio-plastics were frozen with $\mathrm{N}_{2}$ and cry-o-fractured liquids [12]. All samples were mounted on bronze stubs and sputter coated with gold layers before imaging. Surface micrographs of bio- plastic and fracture surface were obtained using electron scanning microscopy (SEM; JSM-6510LA) 10-300.000x magnification with a resolution of $1-10 \mathrm{~nm}$.

\section{Result and Discussion}

HPS was used as the main material to produce bio-plastic due to its ability to increase solubility, reduce gelatinization temperature, retrogradation, and crystallinity, while it improved mechanical properties compared to native starch [8].

\subsection{Mechanical Properties of Bio-plastic}

The results show that tensile strength (TS) was inversely proportional to the elongation at break (EI). The addition of extract concentration resulted in a decrease in TS and an increase in EI (Figure 1). TS and EI of bio-plastic must withstand to the normal level of stress during product distribution and food handling, while they also maintain its integrity and barrier properties [10]. High TS level is generally needed, but the deformation value must also be adjusted to the intended application. All the tensile strength of bio-plastics HPS decreased significantly $(\rho<0.05)$ in the addition of nyamplung extract. It indicated that Nyamplung cake extract addition affected bio-plastic mechanical properties. This may be due to the incompatibility of nyamplung cake extract and HPS biopolymers [10] or the effect of glycerol concentration.

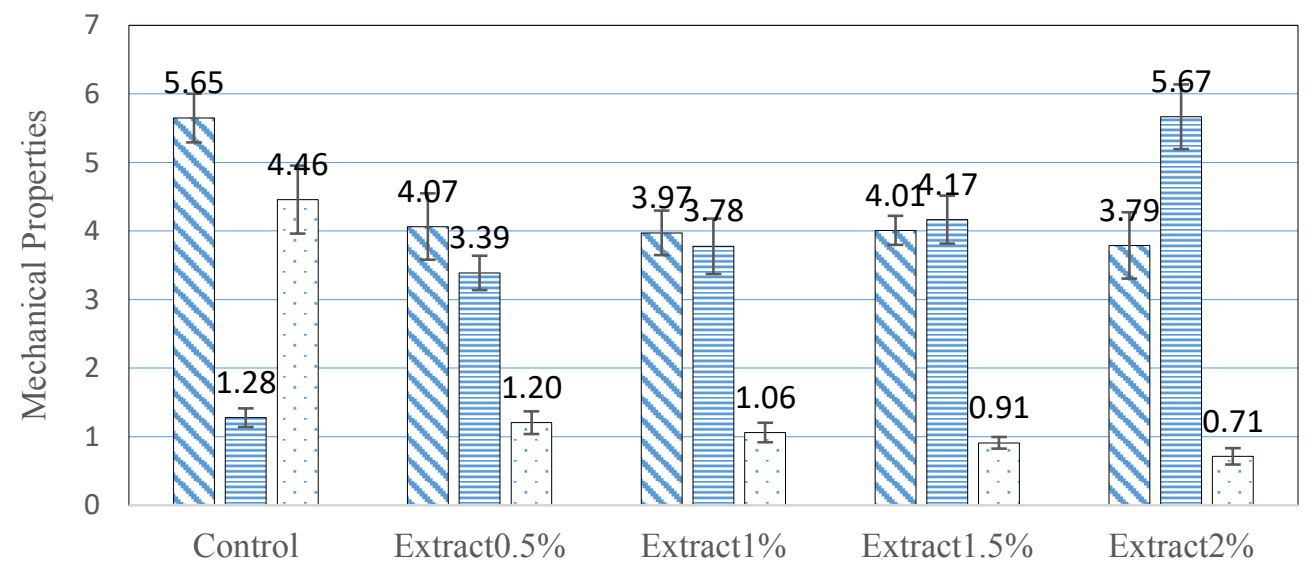

$\triangle$ Tensile Strength (MPa) 目 Elongation at Break (\%) $\square$ Modulus of Elasticity (N/m2)

Fig. 1. Tensile strength, elongation at break and modulus of elasticity of HPS bio-plastics as a function of Nyamplung cake extract concentration (error bar are standard error of the mean five measurements from three separate bio-plastics). Different letter indicates significantly different groups by Duncan's test $(\rho=0.05)$.

The optimum concentration of plasticizer and ingredients is needed to obtain good mechanical and physical properties of bio-plastic for packaging function [18]. It is suggested that nyamplung cake extract contributed to the reduction of intermolecular structural carbon interaction in HPS bio-plastics, which induced the development of heterogeneous bio-plastics structure, led to discontinuity and TS reduction. Besides, Nyamplung cake extract can easily interact with the HPS chain and inhibits the bonds among HPS molecules [10]. Excessive hydroxypropyl groups can cause a sharp decrease in TS of films [19].

The properties of polymer can be modified by using several crosslinking methods. The chemical crosslinking can be carried out by chemical cross-linker addition to the polymer. Besides, there is also natural cross-linker, which can be derived from plant extract in the form of tannin compounds. Tannin is a polyphenol compound 
that contains several $\mathrm{OH}$ groups that can be used as natural cross-linking [20].

\subsection{Water Vapor Permeability (WVP) and Oxygen Vapor Permeability (OVP)}

Figure 2 shows that sample without Nyamplung cake extract as control had the highest water vapor transfer rate through the packaging. WVP among five samples decreased with an average of $1.6116 \times 10^{-11}$. Water vapor transport can be increased by vapor molecules in the air
[7]. Internal factors that influence WVP level are material thickness and type, coating of packaging, and bonding of polymeric materials. The presence of additional additives in bio-plastics may also reduce bio-plastics water sensitivity by protecting the exposure part of water sensitive $\mathrm{OH}$ groups [7].

Besides, the main function of bio-plastic is to block oxygen and moisture transfer from the surrounding atmosphere or between two heterogeneous food products [10]. Therefore, water vapor permeability must be as low as possible.

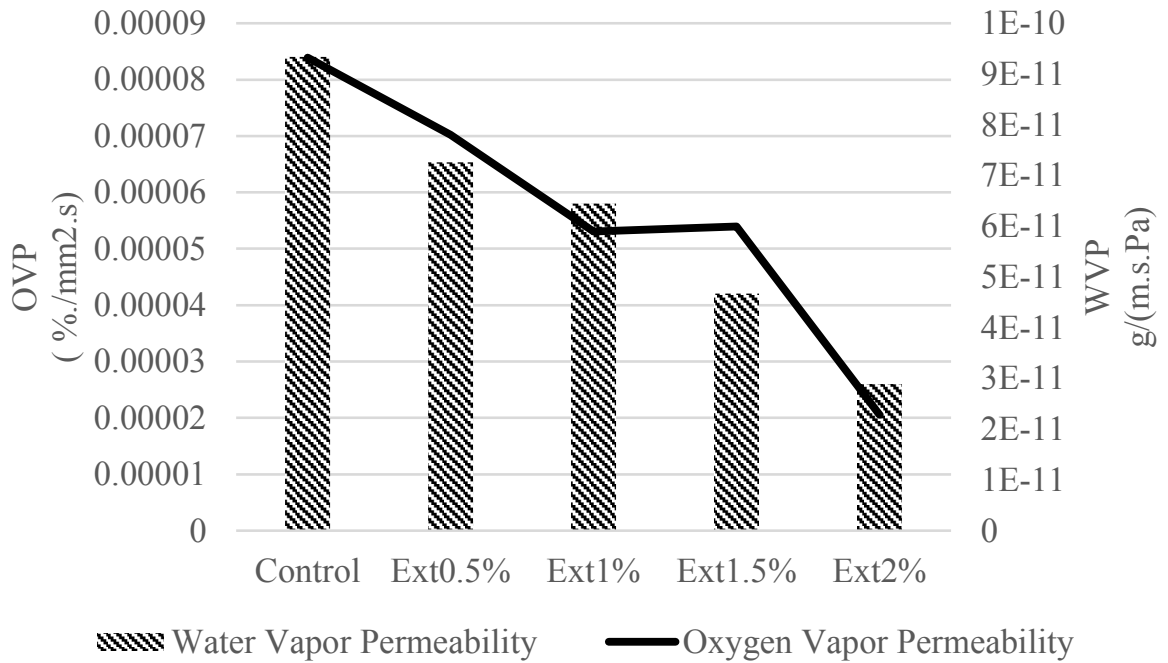

Fig. 2. Water Vapor Permeability and Oxygen Vapor Permeability

Figure 2 shows that the highest OVP was in control sample $\left(9.13 \times 10^{-5} \% / \mathrm{mm}^{2}\right.$.S $)$. It indicated that treatment without nyamplung cake extract addition had high permeability and oxygen transfer compared to others. Oxygen inhibition is one of the important properties that must be considered in starch-based packaging because it can reduce food quality. Gas transportation through the film is very dependent on diffusivity. The pores type of nanocrystals affect gas molecules diffusion and it can increase molecular migration, and thus consequently it limits permeability [21]. This indicated that the addition of nyamplung cake extract can reduce water solubility thus making bio-plastics more resistant to the relative humidity of the atmosphere. This is also possible because of the presence of phenolic compounds found in the extract [10,14]. Phenol, tannin, and flavonoid were detected as prominent secondary metabolites [22]. Therefore the addition of nyamplung cake extract, in general, can reduce WVP and OVP.

\subsection{Water Solubility}

The addition of Nyamplung cake extract reduced water solubility and it caused bio-plastics more resistant to the relative humidity of the atmosphere (fig. 3). Extract addition $(0.5 \%)$ reduced water solubility about $1.59 \%$. This is due to the presence of phenolic compounds found in the extract $[10,14]$.

Water solubility is one of the important properties of bio-plastics for applications in food protection. In general, high water solubility will cause low water resistance. Solubility in water is directly related to the structural properties of proteins and the presence of nonprotein component in bio-plastics, such as phenolic compounds $[23,14]$ 


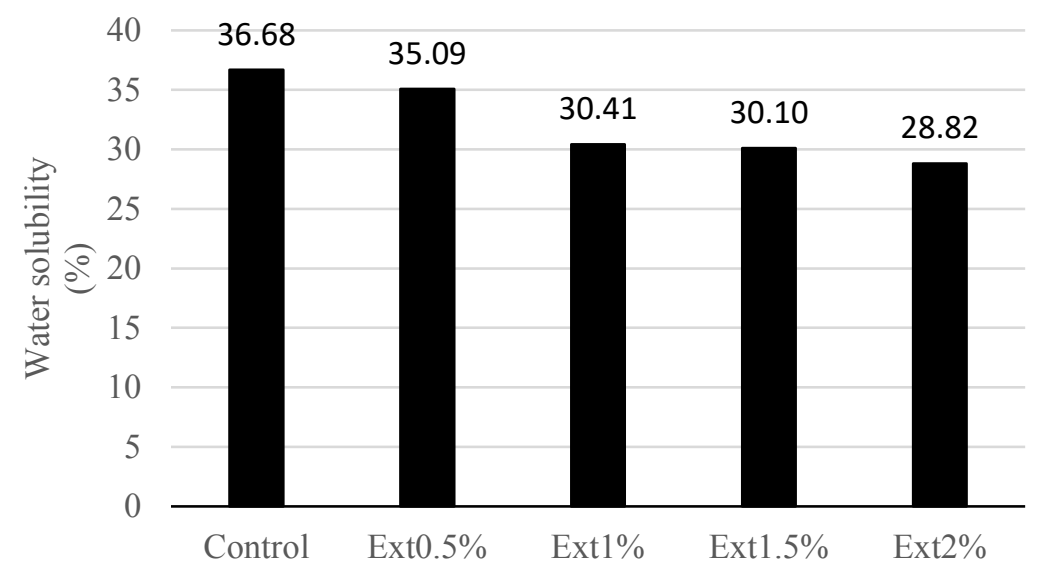

Fig. 3. Water Solubility of Bio-plastic

\subsection{FT-IR Analysis of Bio-plastic}

FT-IR spectroscopy was used to explain molecular interactions between HPS, glycerol, and Nyamplung cake extract in bio-plastics. FT-IR spectrum profiles of five samples had very identical patterns, except the absorbance intensity of peaks. Figure 4 shows FT-IR spectrums of five samples (control, bio-plastics made using $0.5 \%, 1 \%, 1.5 \%$ and $2 \%$ extract) compared to bioplastics with $15 \%$ extract.

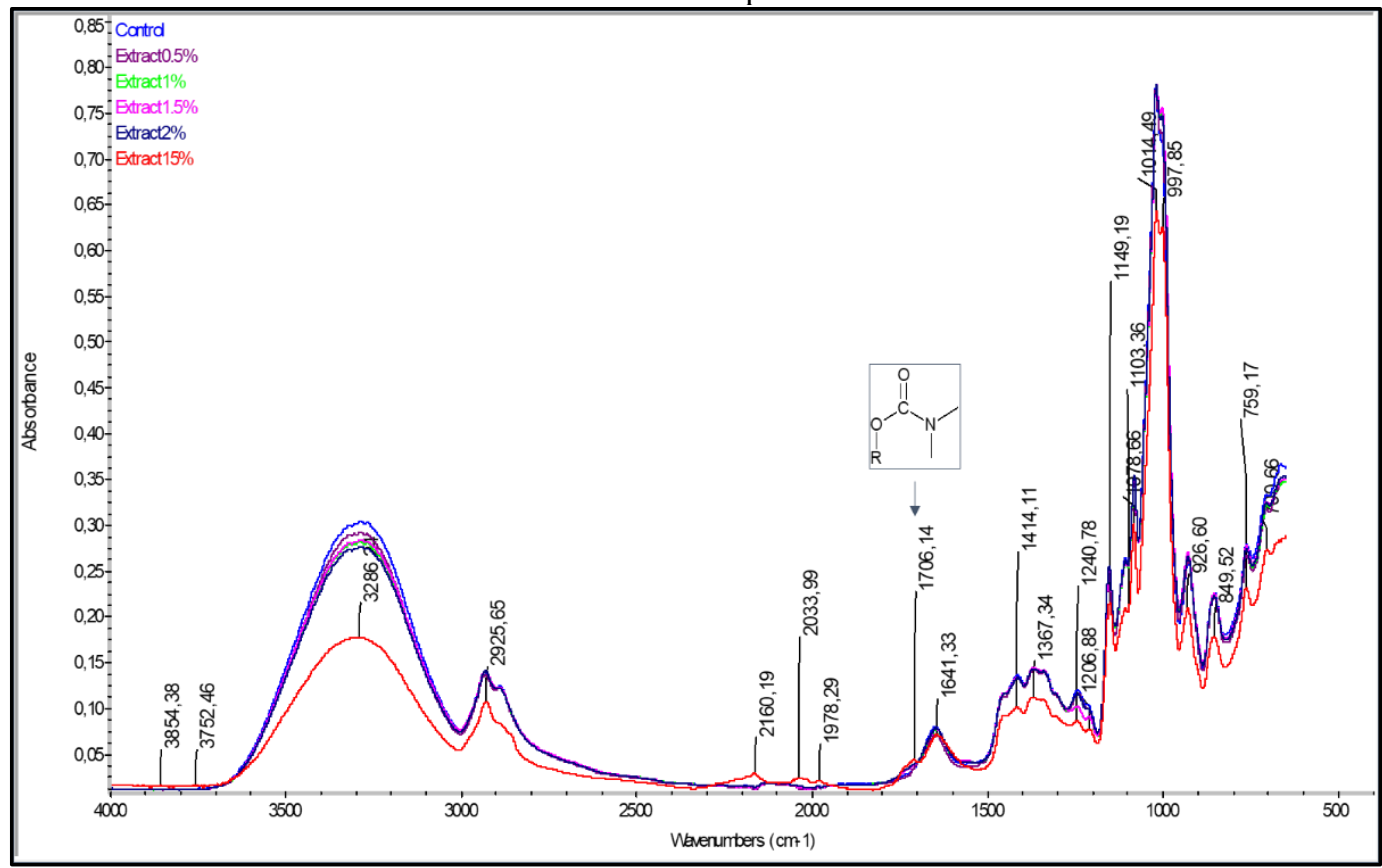

Fig. 4. The Different in FT-IR spectrum between five bio-plastics samples and bio-plastics with a contribution of $15 \%$ extract, found on peak 6 , and band 1706.14 that show amide group.

Band $1\left(3283.06-3284.42 \mathrm{~cm}^{-1}\right)$ was $\mathrm{OH}$ stretching vibration, which represented oximes fragment at various intensities. Band $2\left(2928.59-2926.42 \mathrm{~cm}^{-1}\right)$ shows the vibration stretching of $\mathrm{CH}_{3}$, which represented ketone fragment with weak intensity. Band 3 (1646.49-1639.83 $\mathrm{cm}^{-1}$ ) shows the vibration stretch of $\mathrm{C}=\mathrm{C}$. Band 4 (1367.03-1364.69 $\mathrm{cm}^{-1}$ ) was $\mathrm{R}-\mathrm{SO}_{2}-\mathrm{N}=$ with strong intensity. Band $5\left(1150.40-1149.26 \mathrm{~cm}^{-1}\right)$ was a vibration of $=\mathrm{SO} 2$ with strong intensity. Band 6 (1079.36-1079.07 $\mathrm{cm}^{-1}$ ) was a vibration of $\mathrm{C}-\mathrm{Cl}$ that forms an aromatic compound. Band $7\left(1016.30-1014.82 \mathrm{~cm}^{-1}\right)$ was a vibration of aromatic compounds. Band 8 (925.14$925.87 \mathrm{~cm}^{-1}$ ) was the vibration of $\mathrm{CH}_{2}=\mathrm{CH}_{2}$. Band 9 (850.36-850.82 $\left.\mathrm{cm}^{-1}\right)$ was the vibration of isolated aromatic $\mathrm{C}-\mathrm{H}$. Peak migration and overlap show the formation of certain degrees of intermolecular hydrogen bonds. Similar phenomenon also found in the modified starch system [24].

\section{5 Thermogravimetric Analysis}

Thermal analysis was carried out to determine thermal stability of HPS-extract of Nyamplung cake bio-plastic. The first stage of degradation occurred at a temperature range of $30-200{ }^{\circ} \mathrm{C}$ for all bio-plastic samples based on water and volatile compound loss before the initial decomposition temperature $[25,26]$. The second stage occurred at a temperature range of $200-320^{\circ} \mathrm{C}$ based on 
the chemical decomposition of bio-plastic components. The third stage occurred at $320-600{ }^{\circ} \mathrm{C}$ range based on oxidative degradation of carbon residue formed. Carbon material in the third stage is not decomposed in the presence of nitrogen, but the complete oxidation and $100 \%$ loss of mass occur in the presence of oxygen [26]. About $18-27 \%$ of the remaining degradation of samples at a temperature of $650{ }^{\circ} \mathrm{C}$ was calcium-rich residue and impurity, as well as oil [27].

Table 1. Thermal Stability of HPS-Nyamplung Cake Extract Bio-plastic

\begin{tabular}{|l|c|}
\hline \multicolumn{1}{|c|}{ Bio-plastics } & $\begin{array}{c}\text { Weight Loss } \\
(\%)\end{array}$ \\
\hline Control & 95.82 \\
\hline Extract $0.5 \%$ & 94.78 \\
\hline Extract 1\% & 91.09 \\
\hline Extract 1.5\% & 95.09 \\
\hline Extract $2 \%$ & 84.471 \\
\hline
\end{tabular}

The addition of extract did not have a significant effect on thermal behavior (Table 1). However, the addition of extract increased the onset and end set of

\begin{tabular}{|c|c|c|c|c|}
\hline Control & $\begin{array}{c}\text { Bio-plastic }+ \text { Extract } \\
0.5 \%\end{array}$ & $\begin{array}{l}\text { Bio-plastic } \\
+ \text { Extract } 1 \%\end{array}$ & $\begin{array}{c}\text { Bio-plastic } \\
+ \text { Extract } 1.5 \%\end{array}$ & Bio-plastic + Extract $2 \%$ \\
\hline 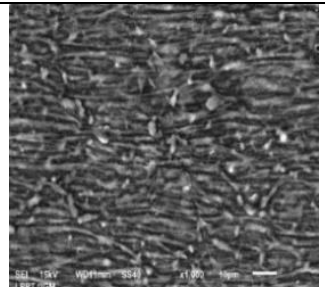 & 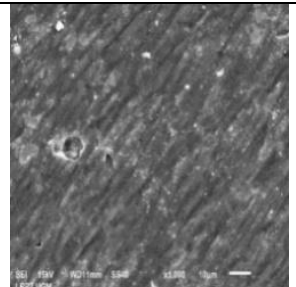 & $x^{6}, 0 \%, 0$ & 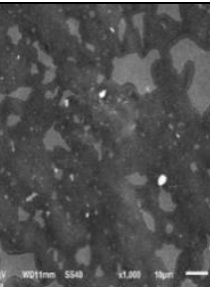 & 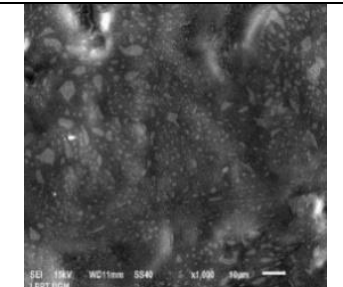 \\
\hline
\end{tabular}

Fig. 5. Scanning Electron Microscopy of Bio-plastics containing 0\%, 0.5\%, 1\%, 1.5\% and 2\% nyampung cake extract.

\subsection{Antimicrobial Analysis of Bio-plastic}

Antimicrobial analysis on gram positive (Staphylococcus aureus), gram negative bacteria (Escherichia coli) and fungi (Aspergillus niger) were conducted using agar diffusion method. This method was based on the measurement of clear zones, or growth inhibition zones, which was caused by bio-plastic after direct contact with bacteria culture $[28,29]$. In this study, higher Nyamplung degradation temperature compared to bio-plastics control and reduced mass loss.

\subsection{Morphology of Bio-plastic}

Morphology of HPS bio-plastics, which was added with Nyamplung cake extract as an antimicrobial agent, was identified by scanning electron microscope (SEM). HPS bio-plastic without extract showed a more compact texture than that of Nyamplung cake extract addition (Figure 5). The presence of Nyamplung cake extract can also be observed in bio-plastic, as some of it appeared as agglomeration on the surface of the sample, which was likely due to the uneven mixing of materials during bioplastic preparation.

Table 2. Inhibition Zone of bio-plastic

\begin{tabular}{|c|c|c|c|c|}
\hline \multirow{2}{*}{ No } & \multirow{2}{*}{ Samples } & \multicolumn{3}{|c|}{ Zone of Inhibition Analysis (mm) } \\
\cline { 3 - 5 } & & E. coli & S. aureus & A. niger \\
\hline 1. & Control Bio-plastics & $14 \pm 1$ & $10 \pm 1$ & ND \\
\hline 2. & Bio-plastics + Extract 0.5\% & $13 \pm 1$ & $25 \pm 1$ & ND \\
\hline 3. & Bio-plastics + Extract 1\% & $15 \pm 1$ & $30 \pm 1$ & ND \\
\hline 4. & Bio-plastics + Extract 1.5\% & $15 \pm 1$ & $25 \pm 1$ & ND \\
\hline 5. & Bio-plastics + Extract 2\% & $23 \pm 1$ & $20 \pm 1$ & \\
\hline
\end{tabular}




\section{Conclusion}

The addition of Nyamplung cake extract caused a decrease in Tensile Strength, Water Vapor Permeability, and Oxygen Vapor Permeability and it increased Elongation at Break. The results showed that addition of Nyamplung cake extract to HPS bio-plastics had good potential in food packaging because of their antibacterial properties, and further research is needed to improve mechanical properties and improve bioplastics morphology (FTIR and Scanning Electron Microscopy Analysis). However, if it is added as an antimicrobial agent in the manufacture of HPS-based bio-plastics it does not have inhibitory power against fungi (A. niger) but effective for inhibiting gram positive bacteria $(S$. aureus) and gram-negative bacteria (E. coli). This is both due to the addition of small extract concentration and bacteria are more sensitive than fungi. Besides, addition of nyamplung cake extract on bio-plastics product also plays a role for creating a good environment because it can increase the value-added of nyamplung waste and make bio-plastics that are easily degraded so that is environmentally friendly.

The authors would like to acknowledge that this research was funded by Beasiswa Unggulan Dosen Indonesia-Dalam Negeri (BUDI-DN)-Lembaga Pengelola Dana Keuangan (LPDP) of Indonesian Ministry of Finance www.crmlpdp.kemenkeu.go.id.

\section{References}

1. K. Cooksey, Oxygen Scavenging Packaging Systems, Encyclopedia of Polymer Science and Technology, 1-10 (2010)

2. S. Y. Sung, L.T. Sin, T.T. Tee, S.T. Bee, A.R. Rahmat, W.A. Rahman, ... M. Vikhraman, Antimicrobial agents for food packaging applications, Trends in Food Science and Technology, 33(2), 110-123 (2013)

3. J.H. Hotchkiss, Food-packaging interactions influencing quality and safety, Food Additives and Contaminants, 14(6-7), 601-607 (1997)

4. Z.A.N. Hanani, Y.H. Roos, and J.P. Kerry, Use and Application of Gelatin as Potential Biodegradable Packaging Materials for Food Products, International Journal of Biological Macromolecules. (2014)

5. R.R. Koshy, S.K. Mary, S. Thomas, and L.A. Pothan, Environment friendly green composites based on soy protein isolate - A review, Food Hydrocolloids, 50, 174-192 (2015)

6. A. Vazquez and M.L. Foresti, Production, Chemistry, and Degradation of Starch-Based Polymers. In D. Plackett (Ed.), Biopolymers - New Materials for Sustainable Films and Coatings (first). Buenos Aires, Argentina: John Wiley \& Sons (2011)

7. S. Liu, P. Cai, X. Li, L. Chen, L. Li, and B. Li, Effect of film multi-scale structure on the water vapor permeability in hydroxypropyl starch ( $\mathrm{HPS}$ )/ $\mathrm{Na}$ MMT nanocomposites, Carbohydrate Polymers, 154, 186-193 (2016)
8. K. Frost, E. Johansson, R. Shanks, S. Goto, and G.M. Kirwan, Thermoplastic starch films: DOE and O2PLS methodology for optimization and increased understanding of polymer processing, Polymer Testing, 32(2), 343-352 (2013)

9. G. Mikael, Production, Chemistry, and Properties of Proteins, Biopolymers - New Materials for Sustainable Films and Coatings, 107-132 (2011)

10. J. Chana-Thaworn, S. Chanthachum, and T. Wittaya, Properties and antimicrobial activity of edible films incorporated with kiam wood (Cotyleobium lanceotatum) extract. LWT - Food Science and Technology, 44(1), 284-292 (2011)

11. F. Rasheed, M.S. Hedenqvist, R. Kuktaite, T.S. Plivelic, M. Gällstedt, and E. Johansson, Mild gluten separation - A non-destructive approach to finetune structure and mechanical behavior of wheat gluten films \&, Industrial Crops \& Products, 73, 9098 (2015)

12. R.A. Espinel, S.K. Flores, and L.N. Gerschenson, Biopolymeric antimicrobial films: Study of the influence of hydroxypropyl methylcellulose, tapioca starch and glycerol contents on physical properties, Materials Science \& Engineering C, 36, 108-117 (2014)

13. M. A. Tung, I.J. Britt, and S. Yada, Packaging Considerations, In Food Shelf Life Stability: Chemical, Biochemical, and Microbiological Changes. CRC Press LLC (2001)

14. M. Kumari, H. Mahajan, R. Joshi, and M. Gupta, Development and structural characterization of edible films for improving fruit quality, Food Packaging and Shelf Life, 12, 42-50 (2017)

15. Y. Pranoto, V.M. Salokhe, and S.K. Rakshit, Physical and antibacterial properties of alginatebased edible film incorporated with garlic oil, Food Research International, 38(3), 267-272 (2005)

16. N. Detduangchan, W. Sridach, and T. Wittaya, Enhancement of the properties of biodegradable rice starch films by using chemical crosslinking agents, International Food Research Journal, 21(3), 12251235 (2014)

17. S. Sun, P. Liu, N. Ji, H. Hou, and H. Dong, Effects of low polyhydroxyalkanoate content on the properties of films based on modified starch acquired by extrusion blowing, Food Hydrocolloids, 72, 81-89 (2017)

18. R. Arham, M.T. Mulyati, M. Metusalach, and S. Salengke, Physical and mechanical properties of agar-based edible film with glycerol plasticizer. International Food Research Journal, 23(4), 16691675 (2016)

19. H.Y. Kim, J.L. Jane, B.P. Lamsal, Hydroxypropylation improves film properties of high amylose corn starch, Industrial Crops \& Products - Elsevier 95, 175-183 (2017)

20. A. Sionkowska, B. Kaczmarek, and K. Lewandowska, Characterization Of Chitosan After Cross-Linking By Tannic Acid, Progress on Chemistry and Application of Chitin and Its Derivatives, $X I X, 135-138$ (2014) 
21. A. González, A. Eceiza, and N. Gabilondo, Starch and cellulose nanocrystals together into thermoplastic starch bionanocomposites, Carbohydrate Polymers J, 117, 83-90 (2015)

22. S.C. Rath, K.C. Nayak, C. Pradhan, T.K. Mohanty, S. Sarkar, S. Toppo, ... S.S. Giri, Evaluation of polanga (Calophyllum inophyllum) oil cake as a non- conventional ingredient in Labeo rohita (Hamilton, 1822) fingerling feed Evaluation of polanga (Calophyllum inophyllum) oil cake as a non-conventional ingredient in Labeo rohita ( $\mathrm{Ha})$. Indian Journal of Fisheries, 64(76207), 75-82 (2017)

23. A. Aguirre, R. Borneo, and A.E. Leon, Antimicrobial, mechanical and barrier properties of triticale protein films incorporated with oregano essential oil, Food Bioscience, 1, 2-9 (2013)

24. L. Zhang, Y. Wang, H. Liu, L. Yu, X. Liu, and L. Chen, Developing hydroxypropyl methylcellulose/ hydroxypropyl starch blends for use as capsule materials, Carbohydrate Polymers, 98(1), 73-79 (2013)

25. A. Patricia, M. Camacho, M.O. Cortez-rocha, J. Marina, E. Brauer, and A. Graciano-verdugo,
Chitosan composite films: Thermal, structural, mechanical and antifungal properties, Carbohydrate Polymers, 82(2), 305-315 (2010)

26. V.M. Azevedo, M.V. Dias, S.V. Borges, A. Letícia, R. Costa, and E. Keven, Development of whey protein isolate bio-nanocomposites: Effect of montmorillonite and citric acid on structural, thermal, morphological and mechanical properties, Food Hydrocolloids, 48, 179-188 (2015)

27. Z. Shen and D.P. Kamdem, Antimicrobial activity of sugar beet lignocellulose films containing tung oil and cedarwood essential oil, Cellulose, 22(4), 27032715 (2015)

28. N.S. Weerakkody, N. Caffin, L.K. Lambert, M.S. Turner, and G.A. Dykes, Synergistic antimicrobial activity of galangal (Alpinia galanga), rosemary (Rosmarinus officinalis) and lemon ironbark (Eucalyptus staigerana) extracts, Journal of the Science of Food and Agriculture, 91(3), 461-468 (2011)

29. D. Zhang, X. Zhao, J. Hou, and Z. Li, Aromatic Amide Foldamers: Structures, Properties, and Functions, ACS Publications, 112, 5271-5316 (2012) 